Check for updates

Cite this: Chem. Sci., 2018, 9, 2159

Received 25th November 2017 Accepted 5th January 2018

DOI: $10.1039 / \mathrm{c} 7 \mathrm{sc} 05057 \mathrm{~g}$

rsc.li/chemical-science

\section{Synthetic fermentation of $\beta$-peptide macrocycles by thiadiazole-forming ring-closing reactions $\uparrow$}

\begin{abstract}
Jonathan G. Hubert, ${ }^{a}$ lain A. Stepek, ${ }^{a}$ Hidetoshi Noda (D) ${ }^{b}$ and Jeffrey W. Bode (D) *a
Macrocyclic $\beta$-peptides were efficiently prepared using a thiadiazole-forming cyclization reaction between an $\alpha$-ketoacid and a thiohydrazide. The linear $\beta$-peptide precursors were assembled from isoxazolidine monomers by $\alpha$-ketoacid-hydroxylamine (KAHA) ligations with a bifunctional initiator - a process we have termed 'synthetic fermentation' due to the analogy of producing natural product-like molecules from simpler building blocks. The linear synthetic fermentation products underwent Boc-deprotection/ thiadiazole-forming macrocyclization under aqueous, acidic conditions to provide the cyclic products in a one-pot process. This reaction sequence proceeds from easily accessed initiator and monomer building blocks without the need for additional catalysts or reagents, enabling facile production of macrocyclic $\beta$-peptides, a relatively underexplored structural class.
\end{abstract}

\section{Introduction}

Macrocyclic compounds are an increasingly valuable platform for biologically active molecules owing to their unique structural properties. Macrocycles have emerged as ideal candidates for the modulation of protein-protein interactions (PPIs), an important area of modern drug discovery. ${ }^{1-3}$ In comparison to their linear counterparts, macrocycles frequently exhibit higher affinity and selectivity for a given target, and often display enhanced in vivo stability. ${ }^{\mathbf{4 - 8}}$

These desirable traits have led to the emergence of innovative methodologies for the generation of libraries of macrocyclic peptides. ${ }^{9-11}$ Contemporary methods include mRNA/ribosome/ phage display technology, ${ }^{12-15}$ selection-based techniques, ${ }^{\mathbf{1 6 , 1 7}}$ DNA-encoded/programming chemistry ${ }^{\mathbf{1 8}}$ and diversity-oriented synthesis. ${ }^{19,20}$ The generation of diverse arrays of macrocyclic compounds using multicomponent reactions, often in a combinatorial setting, has also gained significant attention. ${ }^{21-29}$

While amide-forming cyclizations remain the most common approach to peptide macrocycles, considerable attention has been paid to alternative ring-closing strategies. Leading methods include ring-closing metathesis, ${ }^{30-33}$ alkyne-azide cycloaddition, ${ }^{34-38}$ cross-coupling reactions ${ }^{39-44}$ and Ugi-type reactions. ${ }^{45-47}$ Yudin has recently reported an oxadiazoleforming cyclization, leading to peptides with superior

${ }^{a}$ Laboratorium für Organische Chemie, Department of Chemistry and Applied Biosciences, ETH Zürich, Zürich, Switzerland 8093. E-mail: bode@org.chem.ethz.ch; Web: http://www.bode.ethz.ch

${ }^{b}$ Institute of Microbial Chemistry (Bikaken), 3-14-23 Kamiosaki, Shinagawa-ku, Tokyo 141-0021, Japan

$\uparrow$ Electronic supplementary information (ESI) available: Experimental procedures and analytical data of all new compounds. See DOI: 10.1039/c7sc05057g physicochemical properties. ${ }^{26}$ These are all promising technologies, but require construction of the linear peptides one at a time or cyclization of partially protected precursors.

Our group recently introduced "synthetic fermentation" the production of natural product-like molecules by controlled oligomerization under aqueous conditions without additional reagents, protecting groups, or additives. ${ }^{48}$ The resulting

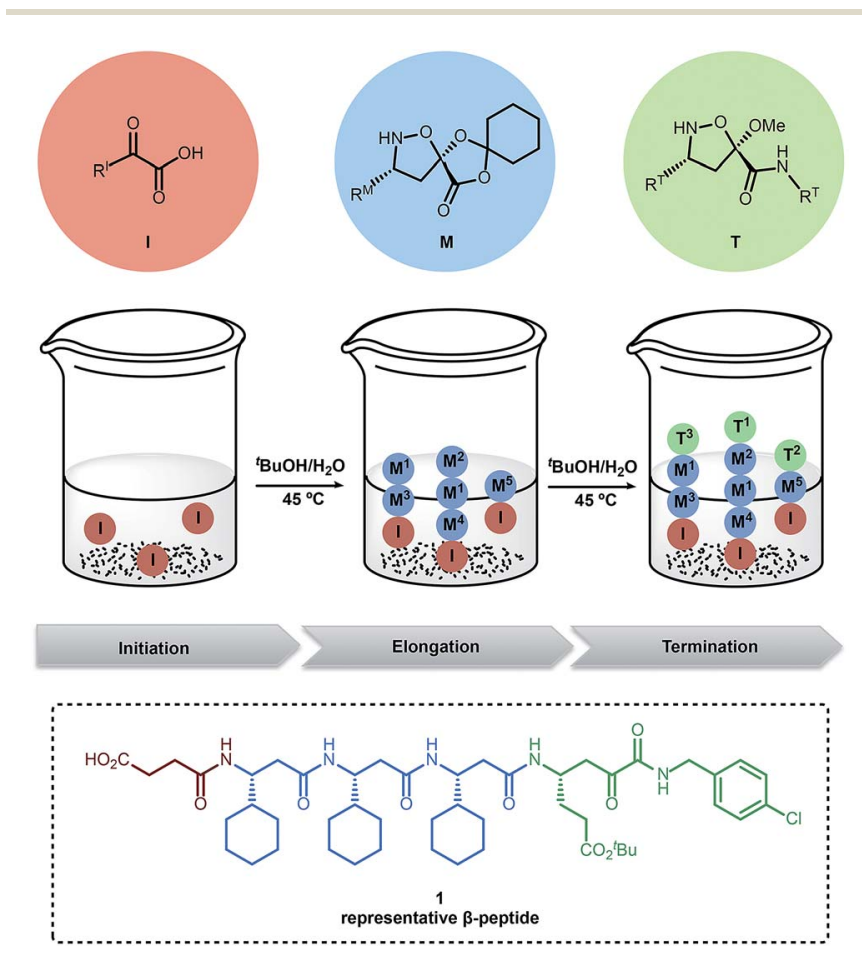

Fig. 1 Preparation of $\beta$-peptide mixtures using synthetic fermentation. ${ }^{48}$ 


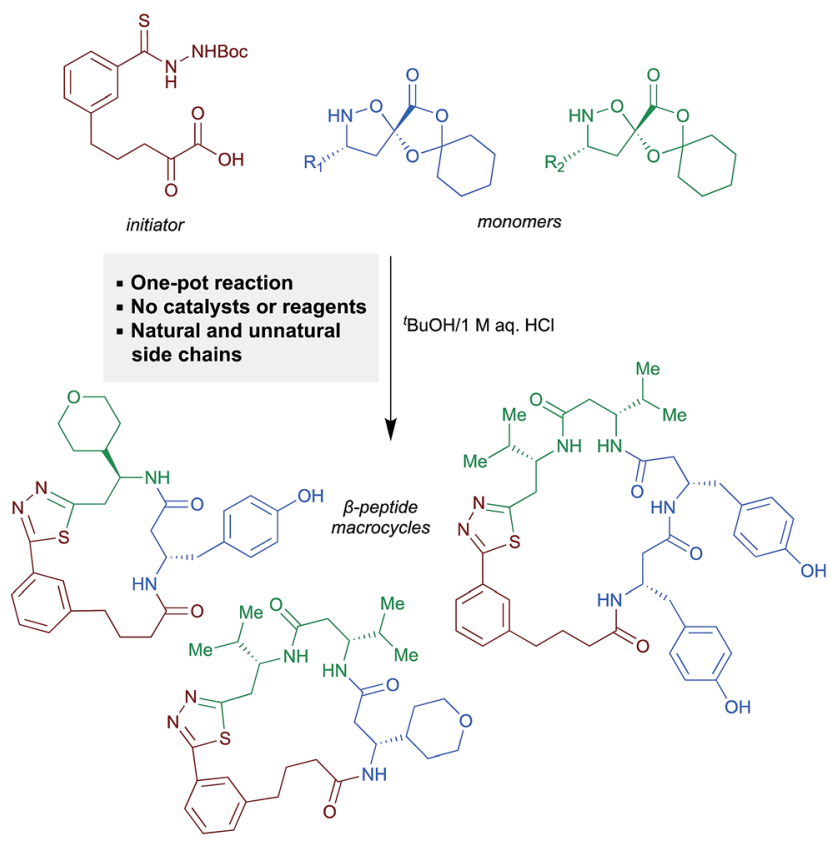

Scheme 1 Synthesis of $\beta$-peptide macrocycles by synthetic fermentation/thiadiazole-forming macrocyclization.

mixtures can be used in biological assays without isolation, and the mixtures are easily reproduced and optimized. In our first implementation, linear, bioactive $\beta$-peptides were produced by combining small building blocks under aqueous conditions (Fig. 1). This report employed three types of building blocks: $\alpha$ ketoacid initiators (I), elongation monomers (M) and terminators (T) and was applied to the discovery of an HCV protease inhibitor. The further optimization of these compounds; however, is limited by the poor properties of small linear peptides as drugs.

Motivated by both the increasing interest in macrocyclic compounds for biological screening and the limitations of linear $\beta$-peptides, we aimed to identify approaches to form macrocyclic peptides under the conditions of synthetic fermentation. In this report, we document a first-generation approach to the synthetic fermentation of $\beta$-peptide macrocycles using a unique thiadiazole-forming ring-closing reaction, including optimization of this novel transformation and its application to the one-pot preparation of $\beta$-peptide macrocycles from simple building blocks (Scheme 1).

\section{Results and discussion}

\section{Cyclization strategy}

Two general strategies for macrocyclization were initially considered (Scheme 2). In the first, cyclization would involve a "lynchpin" terminator that would react with both the Cterminal $\alpha$-ketoacid and an orthogonal functional group on the initiator. Although such approaches are possible, we quickly learned that this process leads to mixtures of cyclic products and various linear precursors. In the second approach, we sought to directly engage the $\alpha$-ketoacid in a macrocyclization
A
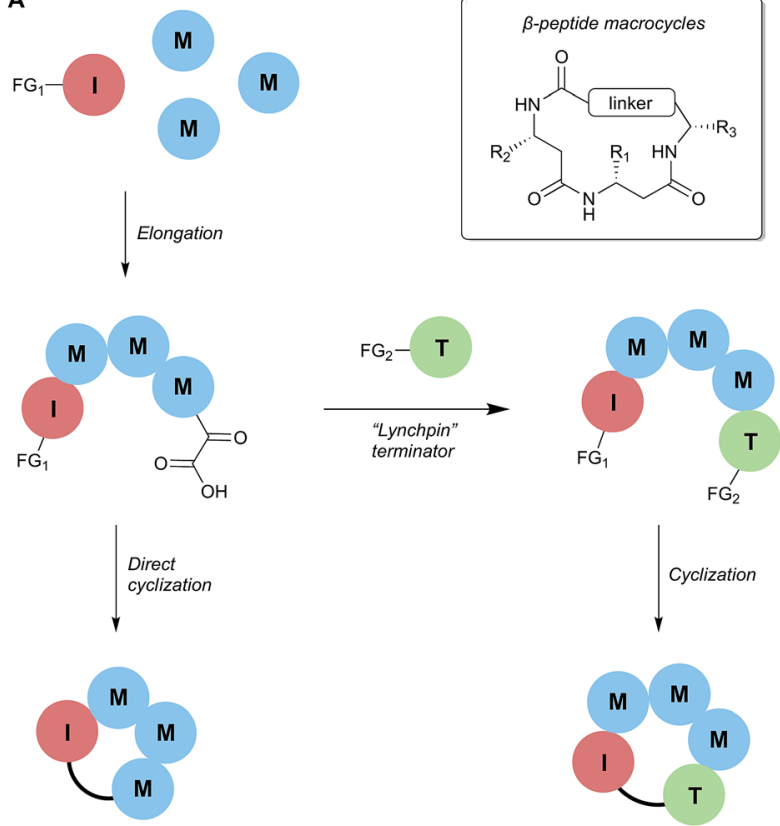

B

Known $n^{50,51}$

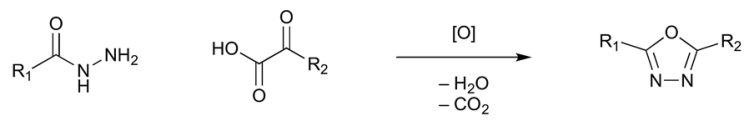

This work

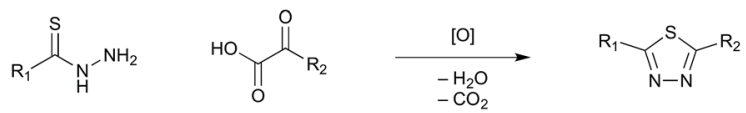

Scheme 2 Strategies to adapt synthetic fermentation methodology for the preparation of $\beta$-peptide macrocycles. (A) General cyclization strategies; (B) proposed 1,3,4-thiadiazole-forming reaction for macrocyclization.

reaction, as this would simplify the overall process by obviating the need for specially functionalized terminators; only an initiator and elongation monomers would be required.

Although ring closure using the KAHA ( $\alpha$-ketoacidhydroxylamine) ligation - an outstanding reaction for peptide macrocycle formation ${ }^{49}$ - is possible, we wished to identify a process that would form something other than an amide bond. We were attracted by recent reports of oxidative coupling of $\alpha$-ketoacids and hydrazides to form 1,3,4-oxadiazoles, ${ }^{50,51}$ the same moiety used in Yudin's exciting work. ${ }^{26}$ We envisaged that using a thiohydrazide in place of the hydrazide would allow for milder oxidation conditions and provide the equally attractive 1,3,4-thiadiazoles.

\section{Intermolecular thiadiazole formation}

To evaluate the proposed thiadiazole-forming reaction, we investigated the intermolecular reaction of benzothiohydrazide (2) and phenylpyruvic acid (3) (Table 1). Under standard synthetic fermentation conditions, condensation of thiohydrazide $\mathbf{2}$ with $\mathbf{3}$ and subsequent cyclization provided adduct $\mathbf{4}$, 
Table 1 1,3,4-thiadiazole formation from thiohydrazide 2 and $\alpha$-ketoacid $3^{a}$

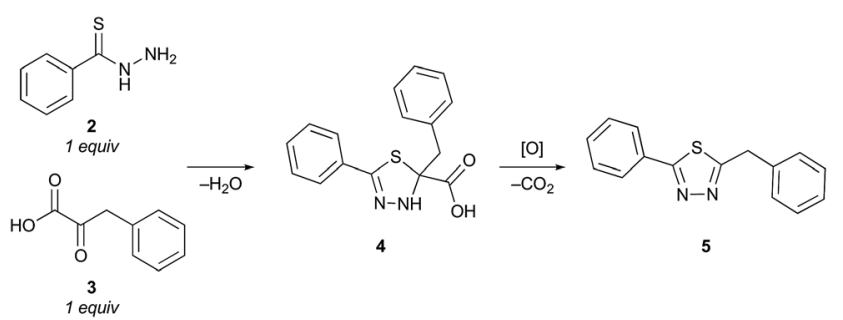

\begin{tabular}{|c|c|c|c|}
\hline Entry & Solvent & Temp. $\left({ }^{\circ} \mathrm{C}\right)$ & Thiadiazole 5: intermediate $4^{b}$ \\
\hline 1 & ${ }^{t} \mathrm{BuOH} / \mathrm{H}_{2} \mathrm{O}(5: 1)$ & 45 & $<1: 20$ \\
\hline 2 & ${ }^{t} \mathrm{BuOH} / 1 \mathrm{M} \mathrm{NaOH}(5: 1)$ & 45 & $<1: 20$ \\
\hline 4 & ${ }^{t} \mathrm{BuOH} / 1 \mathrm{M} \mathrm{HCl}(5: 1)$ & 70 & $>20: 1$ \\
\hline 5 & ${ }^{t} \mathrm{BuOH} / 1 \mathrm{M} \mathrm{HCl}(5: 1)^{c}$ & 70 & $3: 2$ \\
\hline 6 & ${ }^{t} \mathrm{BuOH} / 1 \mathrm{M} \mathrm{HCl}(5: 1)^{d}$ & 70 & $>20: 1$ \\
\hline 9 & $\mathrm{DMSO} / 1 \mathrm{M} \mathrm{HCl}(5: 1)$ & 70 & Complex mixture \\
\hline 10 & Dioxane/1 M HCl (5: 1) & 70 & $1: 1$ \\
\hline 11 & $\mathrm{DMF} / 1 \mathrm{M} \mathrm{HCl}(5: 1)$ & 70 & $3: 2$ \\
\hline 12 & ${ }^{t} \mathrm{BuOH} / 1 \mathrm{M} \mathrm{AcOH}(5: 1)$ & 70 & $1: 2$ \\
\hline 13 & ${ }^{t} \mathrm{BuOH} / 1 \mathrm{M}$ citric acid $(5: 1)$ & 70 & $1: 3$ \\
\hline 14 & ${ }^{t} \mathrm{BuOH} / 1 \mathrm{M}$ TFA $(5: 1)$ & 70 & $>20: 1$ \\
\hline
\end{tabular}

${ }^{a}$ Reactions performed by combining $0.1 \mathrm{M}$ stock solutions of 2 and 3 ( $15 \mu \mathrm{L}$ each) and heating at the given temperature for $16 \mathrm{~h} .{ }^{b}$ Ratio of $5: 4$ determined by LC-MS. ${ }^{c}$ Solvent degassed and reaction performed under nitrogen atmosphere. ${ }^{d}$ Degassed solvent exposed to air prior to reaction set up. ${ }^{e}$ Precipitation observed during the reaction.

while the formation of thiadiazole 5 was not observed (entry 1). Adduct 4 was also the major product formed under basic reaction conditions (entry 2). However, the addition of aqueous $\mathrm{HCl}$ to the reaction media resulted in considerable thiadiazole formation and full conversion to $\mathbf{5}$ was achieved when the reaction was performed at $70{ }^{\circ} \mathrm{C}$ (entries 3-4). The observation that the decarboxylation/oxidation process required for the conversion of $\mathbf{4}$ to $\mathbf{5}$ could proceed without adding an additional oxidant was particularly pleasing, as it would allow the planned macrocyclization reaction to be carried out under simpler conditions than initially anticipated. In the absence of oxygen (degassed solvent under an inert atmosphere) conversion of adduct 4 to thiadiazole 5 was suppressed (entry 5). When oxygen was reintroduced to the previously degassed solvent, full conversion to thiadiazole 5 was observed (entry 6). Combined, these observations suggest that oxygen is acting as the oxidant in this transformation.

The effect of varying the reaction media was investigated. While thiadiazole formation proceeded cleanly when a greater proportion of water was used, precipitation of the product was observed under these conditions (entry 7). The reaction was equally effective when methanol was used instead of $t$-butanol, but the use of other water-miscible solvents either slowed conversion or promoted the formation of side products (entries 8-11). A brief screen of alternative acid sources revealed that, while any acid is sufficient to promote formation of thiadiazole 5 , full conversion is only observed when relatively strong acids (i.e. $\mathrm{HCl}$ or TFA) are used (entries 12-14).
Although not the main focus of this work, we briefly investigated the scope of the oxygen-promoted thiadiazole formation (Table 2).

Preliminary studies revealed that competing dimerization of the thiohydrazide led to the formation of a symmetric thiadiazole side product. Accordingly, a slight excess of the thiohydrazide was used to ensure full conversion of the $\alpha$-ketoacid. Under optimized conditions the model reaction between 2 and 3 afforded thiadiazole 5 in good isolated yield (entry 1 ). $\alpha$ Ketoacids bearing carboxylic acids or protected amines were also tolerated (entries 2-3). The reaction of methoxyphenyl thiohydrazide $\mathbf{1 0}$ and $\alpha$-ketoacid 3 also proceeded cleanly to give thiadiazole 11 in good yield (entry 4). However, pyridyl and alkyl thiohydrazides failed to provide the corresponding thiadiazoles in desirable quantities, due to either slow conversion or the formation of unidentified side products (entries 5-6). The relative success of thiohydrazides $\mathbf{2}$ and $\mathbf{1 0}$ as coupling partners, when compared with $\mathbf{1 2}$ and 15, suggests that a reasonably electron-rich, aromatic thiohydrazide is optimal for this reaction, presumably facilitating the decarboxylation/oxidation process required for thiadiazole formation.

\section{Synthesis of bifunctional initiator 16}

The proposed synthetic fermentation/macrocyclization process required a bifunctional initiator, bearing both an $\alpha$-ketoacid moiety to elicit elongation and a thiohydrazide for subsequent cyclization (Scheme 3). To prevent interference in the 
Table 2 Intermolecular reaction of thiohydrazides and $\alpha$-ketoacids for the synthesis of 1,3,4-thiadiazoles

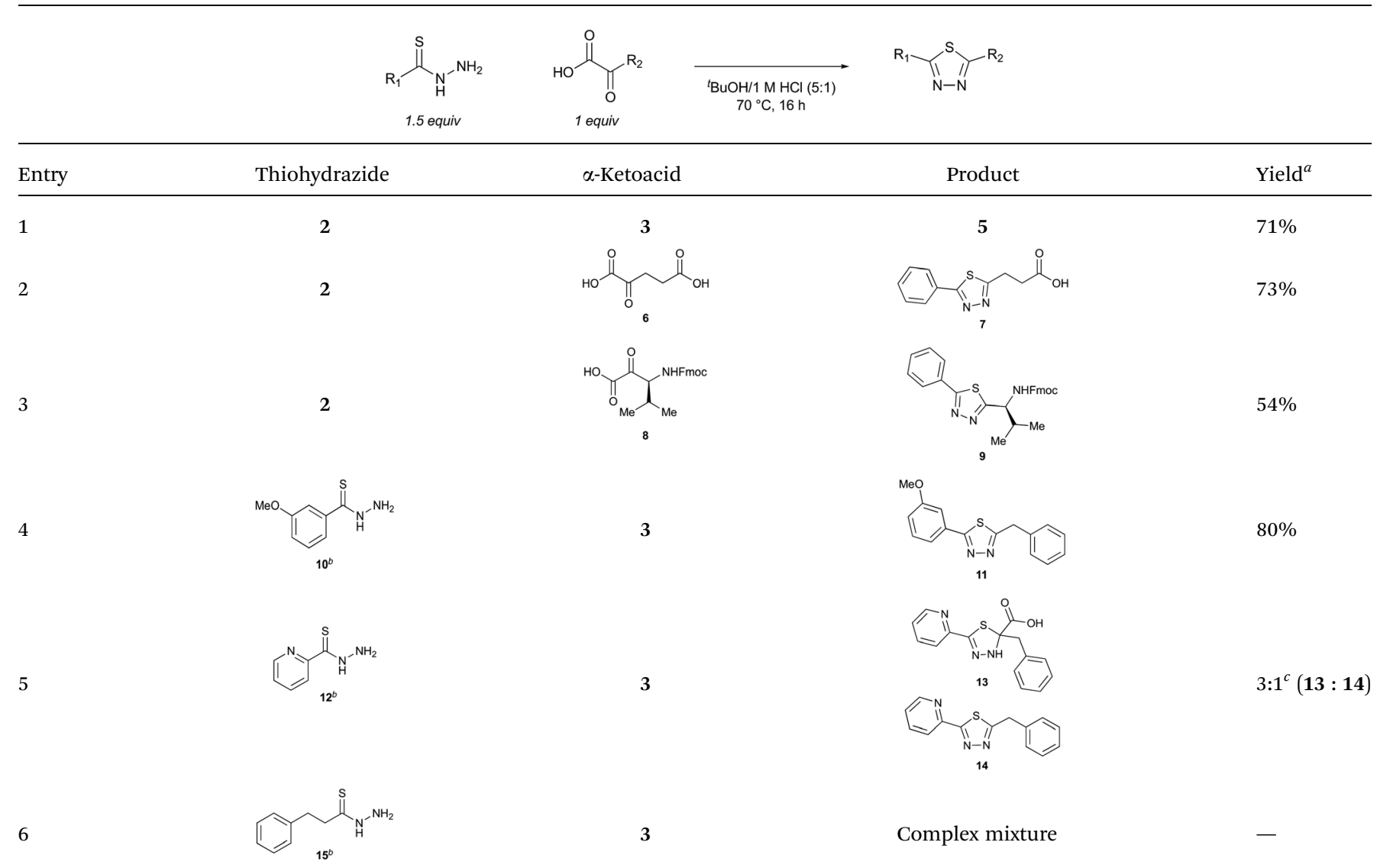

\footnotetext{
${ }^{a}$ Isolated yields after purification by column chromatography. ${ }^{b} \mathrm{HCl}$ salt of thiohydrazide used. ${ }^{c}$ Ratio determined by ${ }^{1} \mathrm{H}$ NMR of crude material.
}

elongation process, we elected to protect the thiohydrazide moiety with a Boc group. We postulated that a Bocthiohydrazide would be stable under the neutral elongation conditions and subsequently cleaved when the reaction mixture was acidified to promote the thiadiazole-forming macrocyclization. As such, $\boldsymbol{\alpha}$-ketoacid $\mathbf{1 6}$ was proposed as a suitable initiator to investigate the elongation/macrocyclization process.

$\alpha$-Ketoacid initiator $\mathbf{1 6}$ was readily synthesized in five steps from commercially available 3 -iodobenzoic acid (17). Following EDCI/HOBt-mediated coupling with Boc-hydrazine 18, a Heck reaction between iodide 19 and allyl alcohol (20) provided aldehyde 21. ${ }^{52}$ An HWE reaction with phosphonate 22 allowed installation of the acetal-protected $\alpha$-ketoacid framework. ${ }^{53,54}$ Subsequent conversion to thiohydrazide $\mathbf{2 4}$ using Lawesson's reagent, followed by unveiling of the free $\alpha$-ketoacid via ester hydrolysis afforded initiator $\mathbf{1 6 .}$

\section{Synthesis of $\beta$-peptide macrocycles}

With bifunctional initiator 16 in hand, we investigated the $\beta$ peptide elongation/macrocyclization reaction (Table 3 ). The elongation monomers used in this process were synthesized according to previous reports. ${ }^{48,54}$ Initially, oligomerization using only one elongation monomer was performed, reducing the complexity of the resulting peptide mixtures and
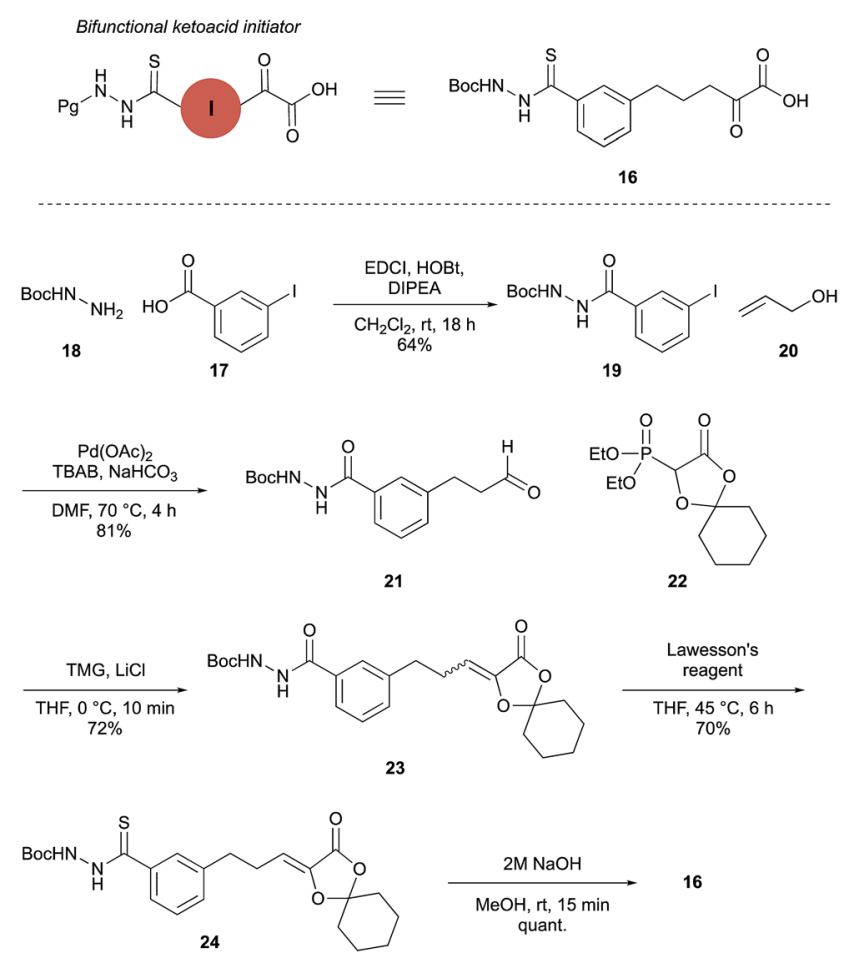

Scheme 3 Synthesis of thiohydrazide-functionalized $\alpha$-ketoacid initiator 16 . 
Table 3 One-pot elongation/deprotection/macrocyclization using one monomer per reaction ${ }^{a}$

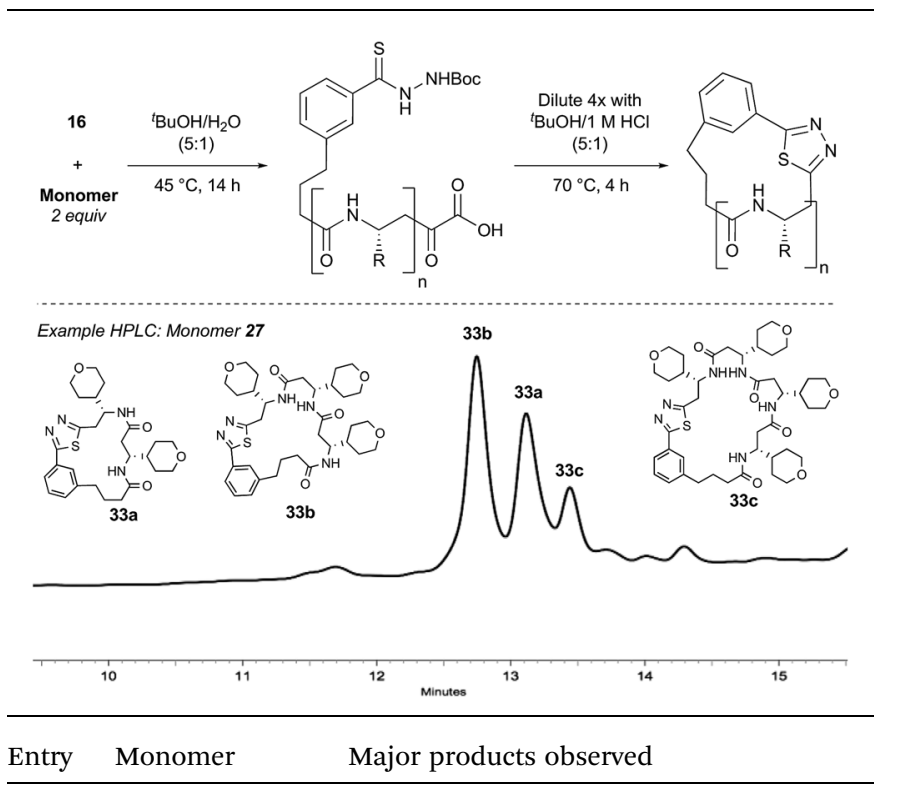

1

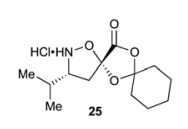

(1)

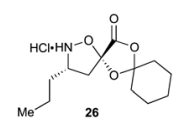

3
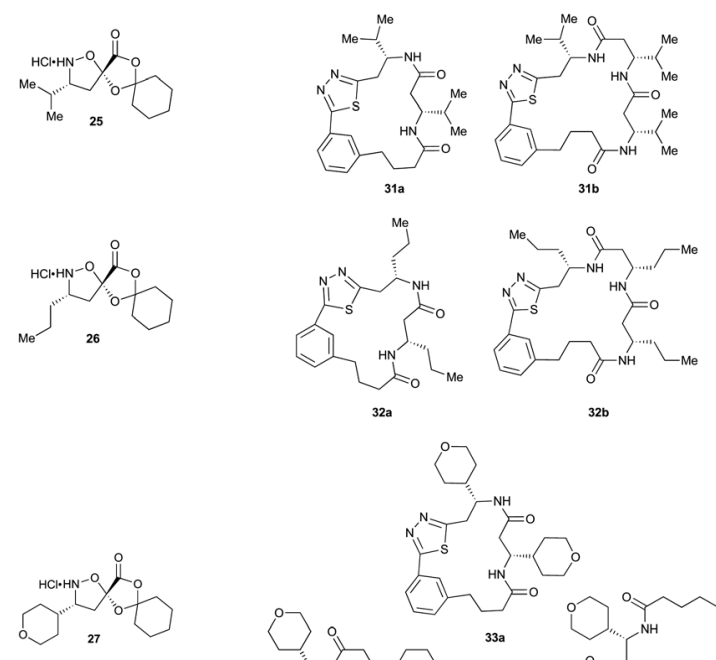

$32 \mathrm{a}$

$32 \mathrm{~b}$
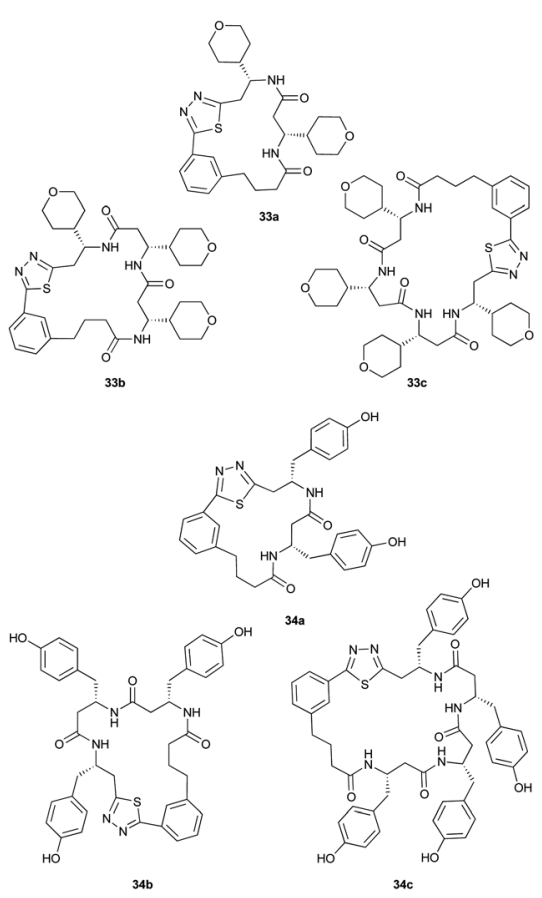

Table 3 (Contd.)

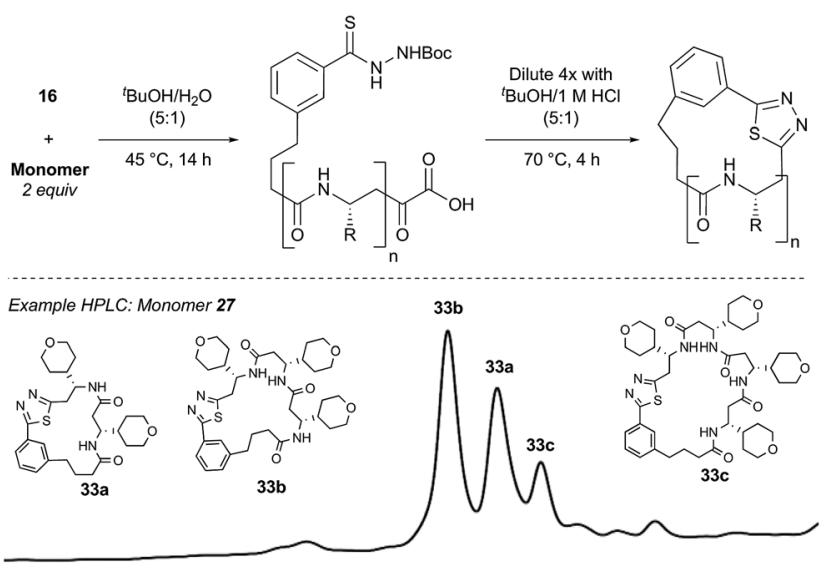

\begin{tabular}{llllll}
\hline & 11 & 12 & 14 & 15 \\
\hline Entry & Monomer & \multicolumn{1}{c}{13} & 14 & 15 \\
\hline
\end{tabular}

5
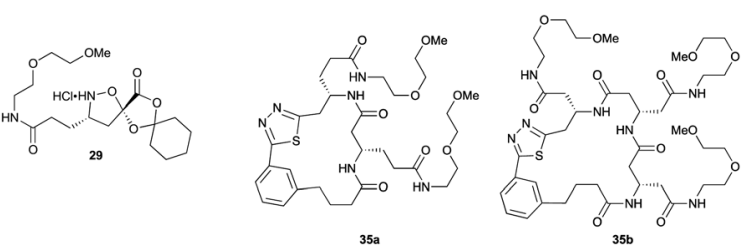

6
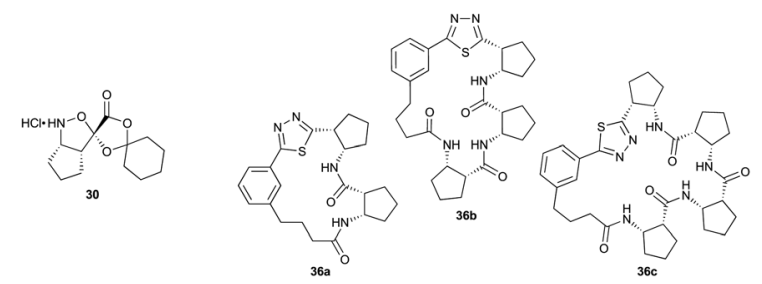

${ }^{a}$ Reactions performed by combining $0.1 \mathrm{M}$ stock solutions of $16(10 \mu \mathrm{L})$ and monomer $(20 \mu \mathrm{L})$, heating at $45{ }^{\circ} \mathrm{C}$ for $14 \mathrm{~h}$, diluting with ${ }^{t} \mathrm{BuOH} /$ $1 \mathrm{M} \mathrm{HCl}(5: 1,90 \mu \mathrm{L})$ and heating at $70{ }^{\circ} \mathrm{C}$ for $4 \mathrm{~h}$. The resulting mixtures were analyzed by HPLC and LC-MS with the major products shown in the table above.

simplifying initial analysis. Elongation was carried out as previously described: two equivalents of the monomer were employed to favor formation of peptides containing 2-3 monomer units. $^{48}$ To promote Boc-deprotection and thiadiazole-forming cyclization, the mixtures of peptides were diluted with ${ }^{t} \mathrm{BuOH} / 1 \mathrm{M} \mathrm{HCl}(5: 1)$ and heated to $70{ }^{\circ} \mathrm{C} .{ }^{55}$ The reactions were monitored by LC-MS and HPLC and the major components of the reaction mixtures are shown in Table 3 (see $\mathrm{ESI} \dagger$ for HPLC/MS traces).

Pleasingly, the desired macrocyclic $\beta$-peptides bearing a 1,3,4-thiadiazole were the major products observed in the reaction mixtures. The predominant products were 17 - and 21membered macrocycles - containing 2 or 3 monomer units respectively - however, larger macrocycles were occasionally seen as minor components of the mixtures. 
Table 4 One-pot synthesis of $\beta$-peptide macrocycles using combinations of two monomers ${ }^{a}$

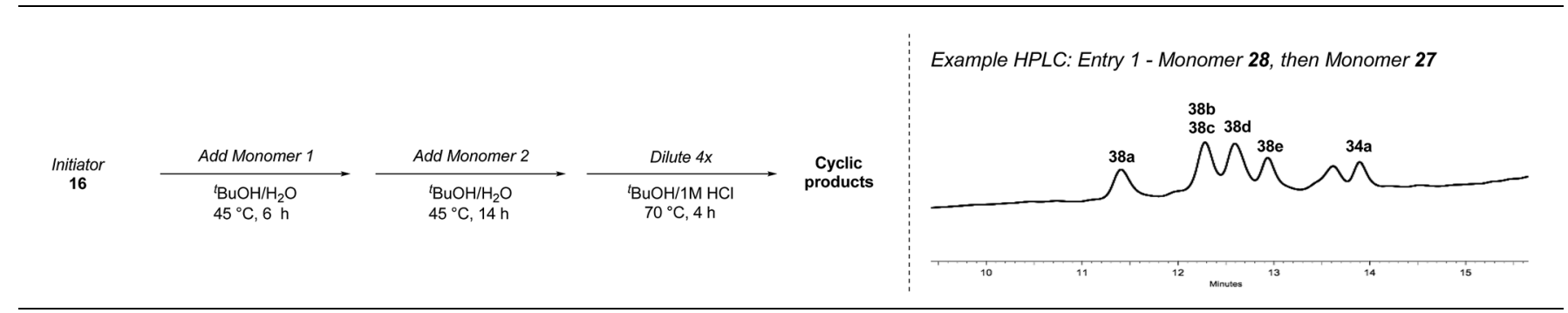

\section{Entry Monomer 1 Monomer 2 Major products observed}

1
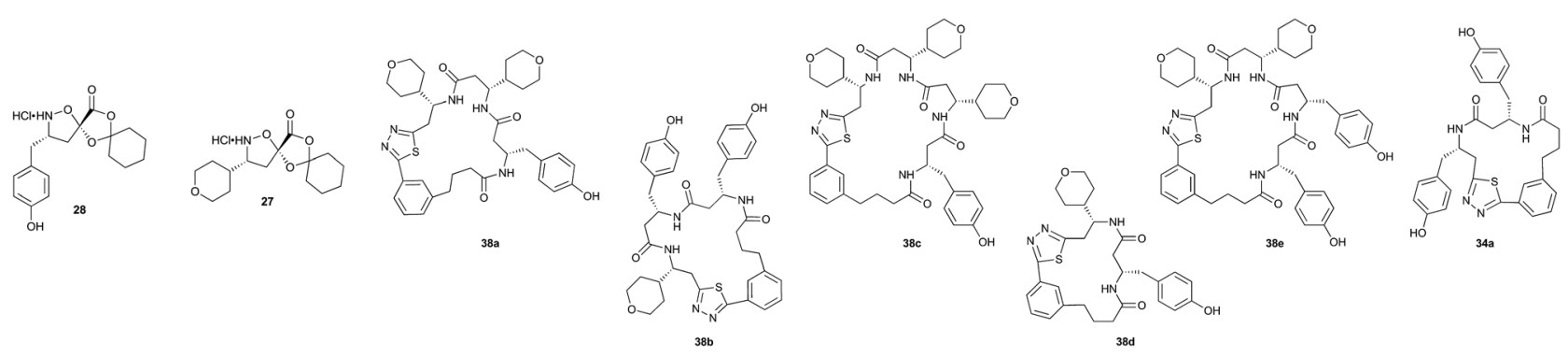

2
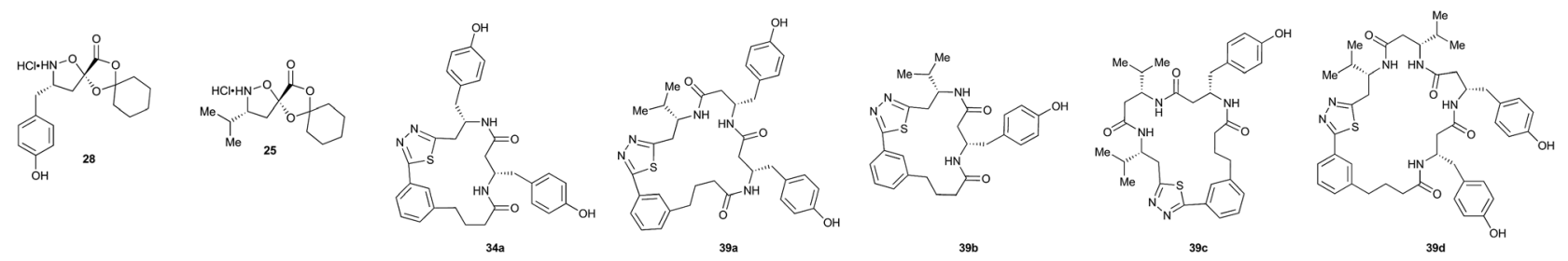

3

Me.
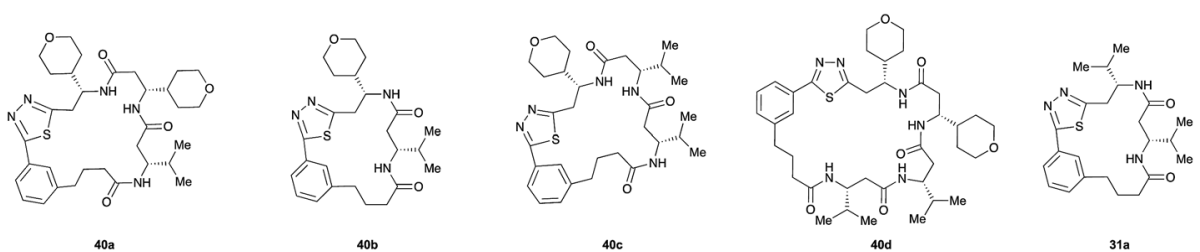

$40 \mathrm{a}$

$40 \mathrm{~b}$
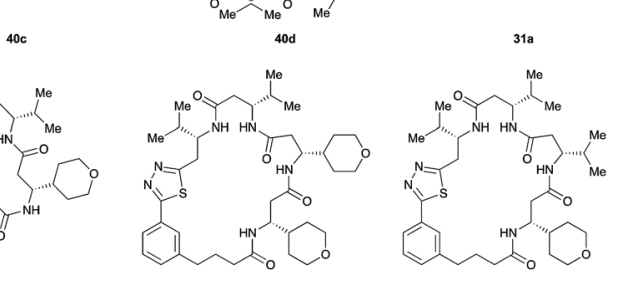

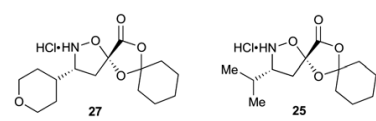
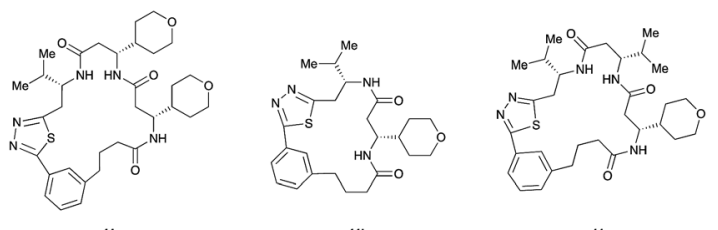

410

41d

410

5

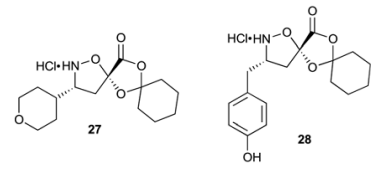

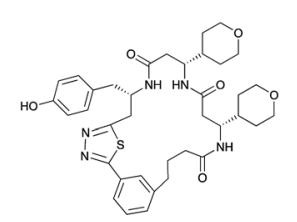

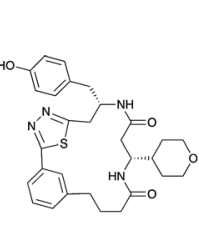

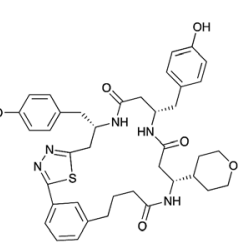

426
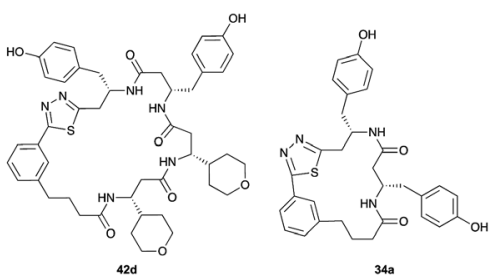

6
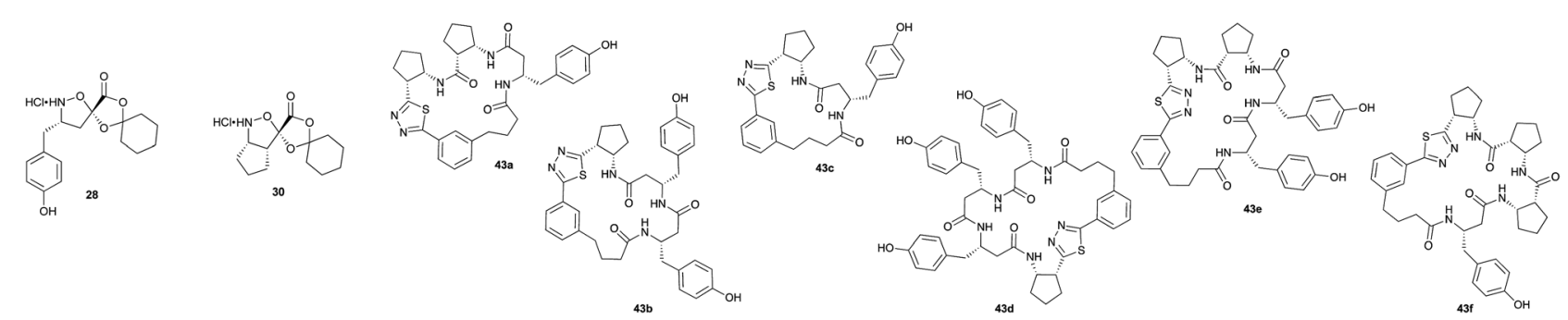


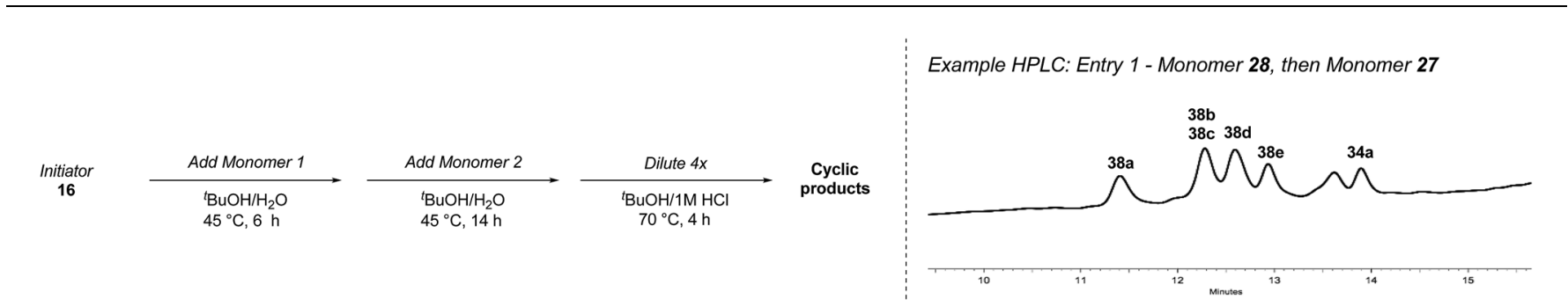

7
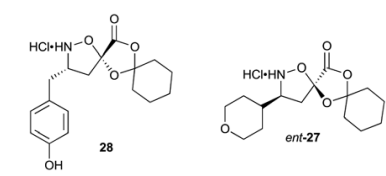

8
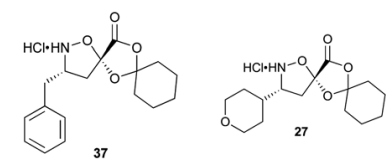

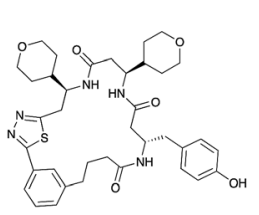

44 a

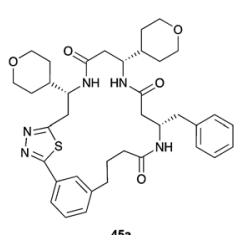

$45 a$
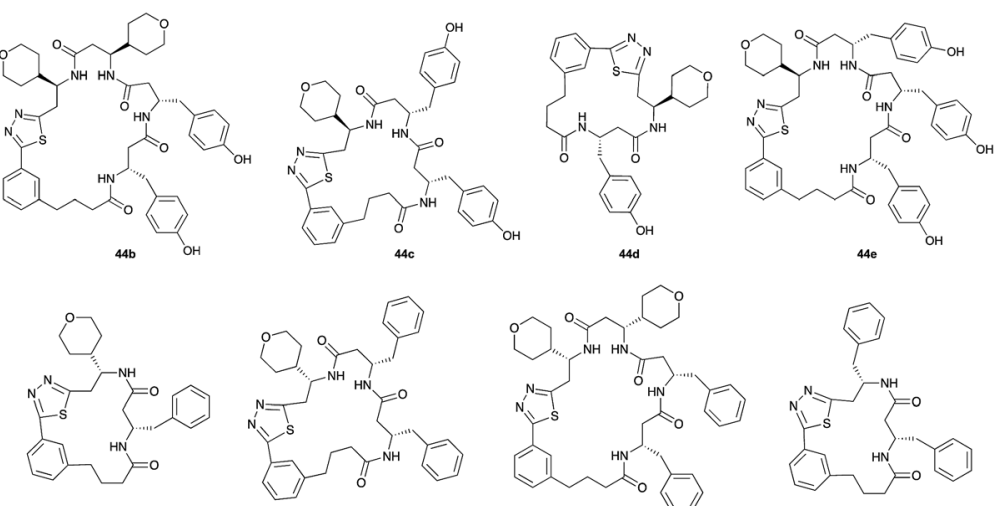

$45 \mathrm{c}$
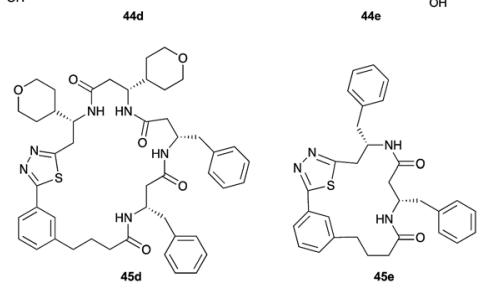

\begin{abstract}
${ }^{a}$ Reactions performed by combining $0.1 \mathrm{M}$ stock solutions of $16(10 \mu \mathrm{L})$ and monomer $1(10 \mu \mathrm{L})$, heating at $45^{\circ} \mathrm{C}$ for $6 \mathrm{~h}$, adding monomer $2(10 \mu \mathrm{L})$, heating at $45^{\circ} \mathrm{C}$ for $14 \mathrm{~h}$, diluting with ${ }^{t} \mathrm{BuOH} / 1 \mathrm{M} \mathrm{HCl}(5: 1,90 \mu \mathrm{L})$ and heating at $70^{\circ} \mathrm{C}$ for $4 \mathrm{~h}$. The resulting mixtures were analyzed by $\mathrm{HPLC}$ and LC-MS with the major products shown in the table above.
\end{abstract}

Interestingly, despite the relative complexity of the overall process (multiple KAHA ligations, Boc-deprotection, intramolecular condensation and subsequent oxidation/ decarboxylation) the formation of the thiadiazole-linked cyclic products is strongly favored. The reactions were carried out with a linear $\beta$-peptide concentration of approximately $8 \mathrm{mM}$ and higher molecular weight compounds resulting from oligomerization of these linear precursors were generally not observed.

Aliphatic monomers 25 and 26 were employed without incident, as was pyran monomer 27 (entry 1-3). The reaction was tolerant to phenol groups, with macrocycles 34a-c observed as the major products when monomer $\mathbf{2 8}$ was used (entry 4). Amide-bearing monomer 29 was also compatible (entry 5). Finally, monomer 30 could also be employed to generate a range of unique peptide macrocycles containing cyclic $\beta$-amino acids (entry 6).

The reactions were generally run on small scale $(1.0 \mu \mathrm{mol})$ to mirror conditions commonly employed for the preparation of synthetic fermentation libraries. However, the reaction scale could be increased $(100 \mu \mathrm{mol})$ without significantly altering product distribution. The major products were isolated by preparative HPLC and fully characterized, confirming successful macrocyclic $\beta$-peptide formation (see ESI $\dagger$ for details).

During our investigations some limitations of the types of monomers that are compatible with this process were identified. Specifically, non-polar aromatic monomers were unsuitable, as the (assumed) products were poorly soluble in solvents required for LC-MS or HPLC analysis. Additionally, monomers bearing acid-sensitive functionality such as tertbutyl esters or Boc-protected amines gave complex reaction mixtures containing only trace quantities of the desired cyclic compounds.

After completion of the reaction, the media could be readily modified to provide solutions suitable for biological screening. The addition of $1 \mathrm{M} \mathrm{NaOH}$ (1/6 of reaction volume) followed by a 10 -fold or greater dilution with a suitable buffer provided solutions of macrocyclic products in the micromolar concentration range containing $<10 \%{ }^{t} \mathrm{BuOH}$ and a $\mathrm{pH}$ equivalent to the chosen buffer.

The key feature of synthetic fermentation is the ability to rapidly prepare mixtures of natural-product like peptides in a controlled fashion. To extend this concept to the formation of macrocyclic peptides, we investigated the synthetic fermentation/macrocyclization process using mixtures containing two different elongation monomers (Table 4). The monomers were added sequentially, with separate elongation periods, in order to control the amino acid sequence of the resulting $\beta$-peptides and limit mixture complexity.

Following the second elongation the reaction mixtures were diluted with ${ }^{t} \mathrm{BuOH} / 1 \mathrm{M} \mathrm{HCl}(5: 1)$ and heated to $70{ }^{\circ} \mathrm{C}$ to effect cyclization. Pleasingly, the enhanced complexity of the $\beta$ peptide mixtures had no noticeable effect on the Boc- 
deprotection/macrocyclization process and the macrocyclic $\beta$ peptides were again the major products.

Monomers 25, 27 and 28, having proven effective in single monomer cyclizations, were used in various combinations to provide a range of macrocyclic compounds (entries 1-5). Including two monomers in each reaction allowed for the combination of acyclic and cyclic monomers (entry 6) as well as monomers with differing absolute stereochemistry (entry 7). Monomers that gave poorly soluble products when used alone (e.g. benzyl monomer 37) could be used in combination with more polar monomers, providing soluble mixtures that were readily analyzed by HPLC (entry 8 ).

Unsurprisingly, given the relative complexity of the overall process, the mixtures sometimes contained minor products that could not be easily identified. While not ideal for the application to biological screening, as these minor side products can increase the chances of false positives, this limitation is balanced by the efficiency in which the macrocyclic products are obtained. The synthesis of a library of such complex, chiral $\beta$-peptide macrocycles by conventional means would require lengthy multistep syntheses and several purification steps for each compound.

For future applications to biological screening, we anticipate that this methodology could be extended to provide diverse mixtures, generated using more monomers per reaction and a single elongation process. Subsequent identification of bioactive compounds from these mixtures would be analogous to isolation of active cyclic peptides from natural sources ${ }^{56-60}$ or semi-synthetic combinatorial libraries. ${ }^{10}$

\section{Conclusions}

In summary, we have established methodology for the rapid generation of macrocyclic $\beta$-peptide libraries from a selection of simple building blocks, enabled by the development of a 1,3,4thiadiazole-forming cyclization reaction between an $\alpha$-ketoacid and a thiohydrazide. The process is carried out in aqueous acidic conditions and does not require additional catalysts or reagents, which will allow for direct biological evaluation of $\beta$ peptide macrocycles, a relatively underexplored structural class.

\section{Conflicts of interest}

There are no conflicts to declare.

\section{Acknowledgements}

This work was supported by the Commission for Technology and Innovation (CTI). We are grateful to Michael Bavand, Philipp Anstätt and Paula Nichols for helpful discussions and support. We thank the LOC MS Service and the LOC NMR Service for analyses.

\section{Notes and references}

1 B. C. Doak, J. Zheng, D. Dobritzsch and J. Kihlberg, J. Med. Chem., 2016, 59, 2312-2327.
2 J. A. Wells and C. L. McClendon, Nature, 2007, 450, 10011009.

3 D. E. Scott, A. R. Bayly, C. Abell and J. Skidmore, Nat. Rev. Drug Discovery, 2016, 15, 533-550.

4 E. Marsault and M. L. Peterson, J. Med. Chem., 2011, 54, 1961-2004.

5 E. M. Driggers, S. P. Hale, J. Lee and N. K. Terrett, Nat. Rev. Drug Discovery, 2008, 7, 608-624.

6 A. K. Yudin, Chem. Sci., 2015, 6, 30-49.

7 J. Mallinson and I. Collins, Future Med. Chem., 2012, 4, 14091438.

8 L. Di, AAPS J., 2015, 17, 134-143.

9 N. K. Terrett, Drug Discovery Today: Technol., 2010, 7, e97e104.

10 A. D. Foster, J. D. Ingram, E. K. Leitch, K. R. Lennard, E. L. Osher and A. Tavassoli, J. Biomol. Screening, 2015, 20, 563-576.

11 C. J. White and A. K. Yudin, Nat. Chem., 2011, 3, 509-524.

12 K. Josephson, A. Ricardo and J. W. Szostak, Drug Discovery Today, 2014, 19, 388-399.

13 N. K. Bashiruddin and H. Suga, Curr. Opin. Chem. Biol., 2015, 24, 131-138.

14 K. Deyle, X.-D. Kong and C. Heinis, Acc. Chem. Res., 2017, 50, 1866-1874.

15 K. Ito, T. Passioura and H. Suga, Molecules, 2013, 18, 35023528.

16 T. Passioura, T. Katoh, Y. Goto and H. Suga, Annu. Rev. Biochem., 2014, 83, 727-752.

17 T. Morioka, N. D. Loik, C. J. Hipolito, Y. Goto and H. Suga, Curr. Opin. Chem. Biol., 2015, 26, 34-41.

18 W. H. Connors, S. P. Hale and N. K. Terrett, Curr. Opin. Chem. Biol., 2015, 26, 42-47.

19 S. Collins, S. Bartlett, F. Nie, H. F. Sore and D. R. Spring, Synthesis, 2016, 48, 1457-1473.

20 C. Cordier, D. Morton, S. Murrison, A. Nelson and C. O'Leary-Steele, Nat. Prod. Rep., 2008, 25, 719-737.

21 R. Liu, X. Li and K. S. Lam, Curr. Opin. Chem. Biol., 2017, 38, 117-126.

22 M. G. Ricardo, F. E. Morales, H. Garay, O. Reyes, D. Vasilev, L. A. Wessjohann and D. G. Rivera, Org. Biomol. Chem., 2015, 13, 438-446.

23 L. A. Wessjohann, O. Kreye and D. G. Rivera, Angew. Chem., Int. Ed., 2017, 56, 3501-3505.

24 T. M. Vishwanatha, E. Bergamaschi and A. Dömling, Org. Lett., 2017, 19, 3195-3198.

25 E. M. M. Abdelraheem, K. Kurpiewska, J. Kalinowska-Tłuścik and A. Dömling, J. Org. Chem., 2016, 81, 8789-8795.

26 J. R. Frost, C. C. G. Scully and A. K. Yudin, Nat. Chem., 2016, 8, 1105-1111.

27 M. Dow, F. Marchetti, K. A. Abrahams, L. Vaz, G. S. Besra, S. Warriner and A. Nelson, Chem.-Eur. J., 2017, 23, 72077211.

28 G. Masson, L. Neuville, C. Bughin, A. Fayol and J. Zhu, in Synthesis of Heterocycles via Multicomponent Reactions II, Springer, Berlin, Heidelberg, 2010, pp. 1-24.

29 R. Madhavachary, E. M. M. Abdelraheem, A. Rossetti, A. Twarda-Clapa, B. Musielak, K. Kurpiewska, 
J. Kalinowska-Tłuścik, T. A. Holak and A. Dömling, Angew. Chem., Int. Ed., 2017, 56, 10725-10729.

30 S. J. Miller and R. H. Grubbs, J. Am. Chem. Soc., 1995, 117, 5855-5856.

31 S. J. Miller, H. E. Blackwell and R. H. Grubbs, J. Am. Chem. Soc., 1996, 118, 9606-9614.

32 H. E. Blackwell and R. H. Grubbs, Angew. Chem., Int. Ed., 1998, 37, 3281-3284.

33 L. D. Walensky and G. H. Bird, J. Med. Chem., 2014, 57, 62756288.

34 S. Cantel, A. Le Chevalier Isaad, M. Scrima, J. J. Levy, R. D. DiMarchi, P. Rovero, J. A. Halperin, A. M. D'Ursi, A. M. Papini and M. Chorev, J. Org. Chem., 2008, 73, 56635674.

35 G. Chouhan and K. James, Org. Lett., 2013, 15, 1206-1209.

36 V. D. Bock, R. Perciaccante, T. P. Jansen, H. Hiemstra and J. H. van Maarseveen, Org. Lett., 2006, 8, 919-922.

37 R. A. Turner, A. G. Oliver and R. S. Lokey, Org. Lett., 2007, 9, 5011-5014.

38 M. Empting, O. Avrutina, R. Meusinger, S. Fabritz, M. Reinwarth, M. Biesalski, S. Voigt, G. Buntkowsky and H. Kolmar, Angew. Chem., Int. Ed., 2011, 50, 5207-5211.

39 K. V. Lawson, T. E. Rose and P. G. Harran, Proc. Natl. Acad. Sci. U. S. A., 2013, 110, E3753-E3760.

40 B. A. Hopkins, G. F. Smith and N. Sciammetta, Org. Lett., 2016, 18, 4072-4075.

41 F.-M. Meyer, J. C. Collins, B. Borin, J. Bradow, S. Liras, C. Limberakis, A. M. Mathiowetz, L. Philippe, D. Price, K. Song and K. James, J. Org. Chem., 2012, 77, 3099-3114.

42 V. Balraju, D. S. Reddy, M. Periasamy and J. Iqbal, J. Org. Chem., 2005, 70, 9626-9628.

43 L. Mendive-Tapia, S. Preciado, J. García, R. Ramón, N. Kielland, F. Albericio and R. Lavilla, Nat. Commun., 2015, 6, 7160.

44 T. Willemse, W. Schepens, H. W. T. van Vlijmen, B. U. W. Maes and S. Ballet, Catalysts, 2017, 7, 74.

45 L. A. Wessjohann, C. R. B. Rhoden, D. G. Rivera and O. E. Vercillo, in Synthesis of Heterocycles via
Multicomponent Reactions I, Springer, Berlin, Heidelberg, 2010, pp. 199-226.

46 M. C. Morejón, A. Laub, B. Westermann, D. G. Rivera and L. A. Wessjohann, Org. Lett., 2016, 18, 4096-4099.

47 E. M. M. Abdelraheem, M. P. de Haan, P. Patil, K. Kurpiewska, J. Kalinowska-Tłúscik, S. Shaabani and A. Dömling, Org. Lett., 2017, 19, 5078-5081.

48 Y.-L. Huang and J. W. Bode, Nat. Chem., 2014, 6, 877-884.

49 F. Rohrbacher, G. Deniau, A. Luther and J. W. Bode, Chem. Sci., 2015, 6, 4889-4896.

50 C. Xu, F.-C. Jia, Q. Cai, D.-K. Li, Z.-W. Zhou and A.-X. Wu, Chem. Commun., 2015, 51, 6629-6632.

51 P. Gao, J. Wang, Z. Bai, H. Cheng, J. Xiao, M. Lai, D. Yang and M. Fan, Tetrahedron Lett., 2016, 57, 4616-4619.

52 M. van Gemmeren, M. Börjesson, A. Tortajada, S.-Z. Sun, K. Okura and R. Martin, Angew. Chem., Int. Ed., 2017, 56, 6558-6562.

53 N. Kaczybura and R. Brückner, Synthesis, 2007, 2007, 118130.

54 T. Gerfaud, Y.-L. Chiang, I. Kreituss, J. A. Russak and J. W. Bode, Org. Process Res. Dev., 2012, 16, 687-696.

55 The thiadiazole-forming macrocyclization reaction was also tested on a purified linear tri- $\beta$-peptide. See ESI $\dagger$ for details. 56 M. Dreyfuss, E. Härri, H. Hofmann, H. Kobel, W. Pache and H. Tscherter, Eur. J. Appl. Microbiol. Biotechnol., 1976, 3, 125133.

57 H. Ueda, H. Nakajima, Y. Hori, T. Fujita, M. Nishimura, T. Goto and M. Okuhara, J. Antibiot., 1994, 47, 301-310.

58 O. Ohno, Y. Ikeda, R. Sawa, M. Igarashi, N. Kinoshita, Y. Suzuki, K. Miyake and K. Umezawa, Chem. Biol., 2004, 11, 1059-1070.

59 K. M. Witherup, M. J. Bogusky, P. S. Anderson, H. Ramjit, R. W. Ransom, T. Wood and M. Sardana, J. Nat. Prod., 1994, 57, 1619-1625.

60 L. T. Tan, X. C. Cheng, P. R. Jensen and W. Fenical, J. Org. Chem., 2003, 68, 8767-8773. 